\title{
My opinions for Local Colleges to Practice General Education
}

\author{
Guangmiao $\mathrm{Xu}^{1, \mathrm{a}}$, Yanfeng $\mathrm{Si}^{2, \mathrm{~b}}$ \\ ${ }^{1}$ Department of Chinese language and Literature, Xingtai ,University \\ Xingtai, 054001, China \\ ${ }^{2}$ Department of Social science teaching, Xingtai University \\ Xingtai, 054001, China \\ aemail: xgm0313@163.com, bemail:xgm0313@163.com
}

Keywords: Local Colleges, General Education

\begin{abstract}
The purpose of the thesis is to apply the research results of general education into local colleges, combining their own real situation to find a kind of reasonable educational stratery. On the one hand, the author intends to build a new idea of general education in practicing it. On the other hand, the author hopes to combine professional education with the general education of local colleges and research the effective strategy in building general education of local colleges. According to a research, the characters of general education lie in using content of courses to cultivate qualified people who can meet the needs of society and build general education with their own local features. Therefore, the thesis mainly has three intentions. First it can further develop the general education of local colleges by researching general education. Second, it can solve problems about the existence and development of higher education. Third, it can help local colleges adapt to development and changes of modern and future ages.
\end{abstract}

\section{Introduction}

Early in the nineteenth century, a professor, coming from American university, combines, at the first time, general education with university students, and then more and more people are interested in researching and discussing it. They hold on different opinions for it. Some people think general education is to cultivate thinking ability, others regard it as preliminary education, Someone also regards it as academic training before students who come from institutions of higher learning enter into the stage of professional education, Somebody also believe that general education is a life-long education. What's more several people regard it as an education to develop all-round persons. Therefore, it is not difficult to find that educational circles haven't formed a formal definition about general education and it is just a kind of idea. Considering all universities have difficulty in practicing general education, some scholars believe that general education can only be practice in famous universities, such as Beijing University, and Local Colleges have no abilities and conditions to practice it. However, under the new setting of reforming general education, local colleges have possessed enough abilities and conditions to practice general education and they are badly in need of general education with their own characters. The author believe that the most important thing that local colleges should do is to raise educators'creative awareness, so that they can explorer a road of general education which fitting the development of local colleges.

The author think educators shouldn't confine the results of general education which have been researched by ancestors. They should endow it with new meaning. Meanwhile, educators should proceed from the actual situation of students who come from local colleges. To seek for educational strategies fit local colleges. The thesis mainly analysis general education of local colleges so that the author can exert little contribution for the development of universities'quality education...

\section{Building core idea of general education}

What is general education? Scholars hold on different opinions. Educators both at home and abroad are trying a general education and doing their best to give a proper definition for general 
education. But as far as the present situation is concerned, many scholars can't have a clear understanding for general education or they can't give an exact definition for it. There is no denying that general education belongs to the extension of quality education. But general education isn't equal to develop all rounders for it is impossible for persons to become versatile people from the perspective of human' s Nature and their development. Han $\mathrm{Yu}$, the initiator of ancient literature movement has ever said:" one might have learned the doctrine earlier than the other, or might be a master in his own special field. A person who can obtain great achievement in a field is commendable, but he can't know anything. However, it doesn't mean that a person can't become a brilliant man of wide learning or possess numerous gifts and considerable arts for a versatile person aren't equal to all-rounder.

A versatile person is not inborn, for school education, especially university education plays an important role. Colleges and universities can not only open selective course .Meanwhile they also can not only advocate liberal arts and creative education which should be beneficial to cultivate students' creative thoughts and abilities and need to create conditions so that students are good at finding useful things giving guidance's so their lives, study and future jobs from books. The aim of general education is not to cultivate a versatile person but to develop a brilliant man of wide learning. For example there are many brief introductions about authors and their works in modern literature. If students are required to recite these knowledge there has no any meaning. The authors think students should be asked toanalyze successful experience of the authors and their works. For instance universities can teach social function that literature save people's spirits by telling about the story of LuXun who give up learning medicine to go in for literature. They also can teach social life from the success and failure of character coming from literature works. All in all, general education is not all rounder's education but general of educational idea.

\section{The possibilities of Practicing General Education of Local colleges}

Though local colleges follow the traditional form of professional education, general education has become an international item accepted by famous universities all over the world. Chinese educational world also attach importance to general education. It is obvious that the idea of general education has been deeply rooted among the people. Various channels of employment make students yearn for general education. Though, at present, teachers and students coming from local colleges haven't a clear recognition for general education, the phenomenon that employment problem of college students is not suitable to their special training is very common. For instance, those whose special training is Chinese are to be a guiders when are to be sellers. This is a universal failure of college students who graduate from local colleges. Many students make remarkable achievement when staying in schools and they can real off what they have learnt. However, it is a pity that they can't use their knowledge when entering into society and academic certificate can't help them to seek for satisfied jobs. For this phenomenon, this is a manifestation of failure of traditional special training. So, the author thinks whether universities should give up special training to explore a road of general education or not. The author believes it is not the fault of special training, but the idea and form of traditional special training. Nobody has said special training just teach specialties, for any knowledge is interlinked. As far as Chinese specialty is concerned, the various subjects of Chinese specialty are not only interlinked, but also it contact with other specialties. For example, aesthetics is not only a branch of philosophy, but also is related closely to literature and art. Though out the long history of China, aesthetes are also artistic theoreticians and philosophers. Many aesthetes and they also the basis of theories, which is beneficial for us to build harmonious relationship and create beautiful life. Take the subject of Chinese specialty for example; every subject of Chinese specialty is not isolated, for the theories of literature can't separate from literary works. Meanwhile, if you want to teach literature lesson, you must be dependent on the theories of literature. To a certain extent, a literature lesson is equal to a lesson of appreciating literature and a lesson of literary theory is equal to a lesson of showing creative experience and 
results. This is general education. Many colleges have their own majors and their own characters to run teaching. As long as the teachers and students of local colleges possess the idea of general education, local colleges have the possibilities to practice general education.

\section{Combining special Training with General education of local colleges.}

Some scholars think general education refers to cultivate a versatile person. The aim of it is to make students know everything. Li Jionglang, the initiator of general education, has ever said that what he hopes is to learn every course. That is to say a person who learns science needs to know poems, history and philosophy. For example, you feel very pain when doing questions about calculus, reading poetry of the Tang Dynasty will help you get inspiration of solving calculus. He even thinks special training takes into bachelor or researchers of companies' hands. Therefore, it is not difficult for us to find that Li Jionglong combine literal arts with science. As a matter of fact, it is impossible for a person to know everything and it is no need to do everything by him. Take Tang Seng for example, he needn't to lead horse and shoulder pole by himself to beg alms or even to subdue demons and monster. As long as he persists his mission to go on a pilgrimage of the Buddhist Scripture, and manage his own team, he has finished his task. Starting from the actual facts of local colleges, special training is the beginning of education. The mission of general education is not to cultivate all-rounder, but to combine with special training. The author thinks the most important task of general education is to make the lessons of every major become more systematic and general systematic study is to put the lesson of every major into a whole system of which not refers to major system, but to the employment system of students. As far as the Chinese specialty is concerned, local colleges still open these special courses which needn't do a great change, but they need to change the teaching forms of teachers. In other words, teaching contents can follow the original arrangement, but the teaching forms must be changed, which gives a great challenge for teachers, for they can't simple read books on class or simple explain these unintelligible theoretical knowledge, but they can think good ideas to apply the knowledge into practice and help students find useful things from books. The goal of general education is to teach students to draw lessons from those results and experience which have been done by ancestors. There is a different between readings

Not only reading thin books but also reading thick books, Reading thin books are to find out problems and form a clear frame in one mind. Reading thick books are to find out knowledge beyond the problems and think out the solution .No matter what problem one wants to research, he must find out a point. Professional training is the point of general education.

\section{Cultivating social Talents by Teaching Knowledge as the Key Point of General Education.}

General Education is not simple o connect different subjects or majors. The most important task of it is to build a bridge between the teaching contents and social practice. Some knowledge from books just adapt to exam. After finishing exam, the knowledge has no any use. The core purpose of General Education is to help students to get social capital of becoming a social person, rather than measuring teaching by marks. Social capital that student need includes intelligent elements, which can plan their careers, technological method, ethics accomplishment, life wisdom, spiritual value, cultural competence and morality belief, etc. In the age of exchange between new and old knowledge, any university education can't finish all knowledge structure that a student need to satisfy requirement of employment. At the same time, the ultimate goal of special training is not just teach students professional knowledge or skills, but help them to get spiritual experience in the field of researching knowledge, which is beneficial to development of their whole lives. Though these students don't seek for a job in their professional fields, they can become persons with academic spirit and solve practice problems in the perspective of researching special training. 
Therefore, HaQinsi, the headmaster of Chicago, even describe general education those in terms of young, concepts and methods to teach continuously them. The purpose of education is not the form of manpower, but the development of manhood. The author think special training can connect with General Education, but the key point should make efforts in cultivating the development of social talents...

\section{General Education with the Features of Local Colleges}

General Education of Local Colleges should have their characters. All Local Colleges should practice general education by combining their local features. The big cities, like Bei Jing, Tian Jin, can arrange their resources, making full use of teachers' resources. For example, they can invite professors or students to get credits in other colleges. Meanwhile, local colleges may use the successful experience about optimum distribution of resources receiving from universities located in big cities. As for teacher's students of local colleges, as teacher's stations can't be satisfied with all

graduates, many students are in a puzzle about the special training and choosing careers. In view of existing situation, schools should encourage students to choose some courses in other majors. In addition, school should provide more convenient conditions for students. As for the course students have chosen, as long as they are appropriate for colleges' regulations, colleges should confirm students' credit, which not advocate how many hours students must study, but initiate strict examination system and check students' work in a scientific approach. What's more, local colleges should strengthen their teachers' awareness of general education. On the other hand, local colleges should encourage teachers to practice in real social life and build a practice base linking universities and companies. They also can organize these teachers who haven't classes for a longtime to practice in big companies or relative units. What's more, local colleges should try their best to manage teaching situations violating teaching regulations so that they can develop the deepest potential of teachers and students .For example, they can make teachers choose their students and vice versa. One class can be arranged in the same time, but teach in different classrooms, which can give students opportunities to choose freely their teachers.

\section{Conclusion}

ALL in all, the general education of local colleges needs to be more clear and further develop. Only in this way can the general education of local colleges final out a road fitting for them.. Especially, providing a wide platform in theory and practice in the framework of the general education, to achieve the coexistence and development of multiculturalism. In this background of knowledge, the philosophy of general education should become a development road of the local education.

\section{References}

[1] DH. Wang, Into American education, People's education press, 2004.

[2] KJ.Huang, American university's general education, Taiwan normal university, 1995

[3] ML Li, General education, an opinions for college education, Beijing: Qinghua university press, 1999

[4] H.Xu, Theory of university teaching, Zhejiang university press, 2004

[5] JS.Wang, The culture of modern university, Beijing university press, 2002 